\title{
Eagle Burials on Red River Caddo Sites
}

Timothy K. Perttula

Heritage Research Center, Stephen F. Austin State University

Follow this and additional works at: https://scholarworks.sfasu.edu/ita

Part of the American Material Culture Commons, Archaeological Anthropology Commons, Environmental Studies Commons, Other American Studies Commons, Other Arts and Humanities Commons, Other History of Art, Architecture, and Archaeology Commons, and the United States History Commons

Tell us how this article helped you.

This Article is brought to you for free and open access by the Center for Regional Heritage Research at SFA ScholarWorks. It has been accepted for inclusion in Index of Texas Archaeology: Open Access Gray Literature from the Lone Star State by an authorized editor of SFA ScholarWorks. For more information, please contact cdsscholarworks@sfasu.edu. 


\section{Eagle Burials on Red River Caddo Sites}

Creative Commons License

(c) (i) (8)

This work is licensed under a Creative Commons Attribution-NonCommercial 4.0 International License 


\section{Eagle Burials on Red River Caddo Sites}

\section{Timothy K. Perttula}

A wide variety of birds are found in faunal assemblages from Caddo sites in southwest Arkansas, northwest Louisiana, eastern Oklahoma, and East Texas, particularly turkey as well as ducks and geese. One of the rarest avifauna recovered on Caddo sites of any age is that of the eagle, including bald eagles (Figure 1) and golden eagles.

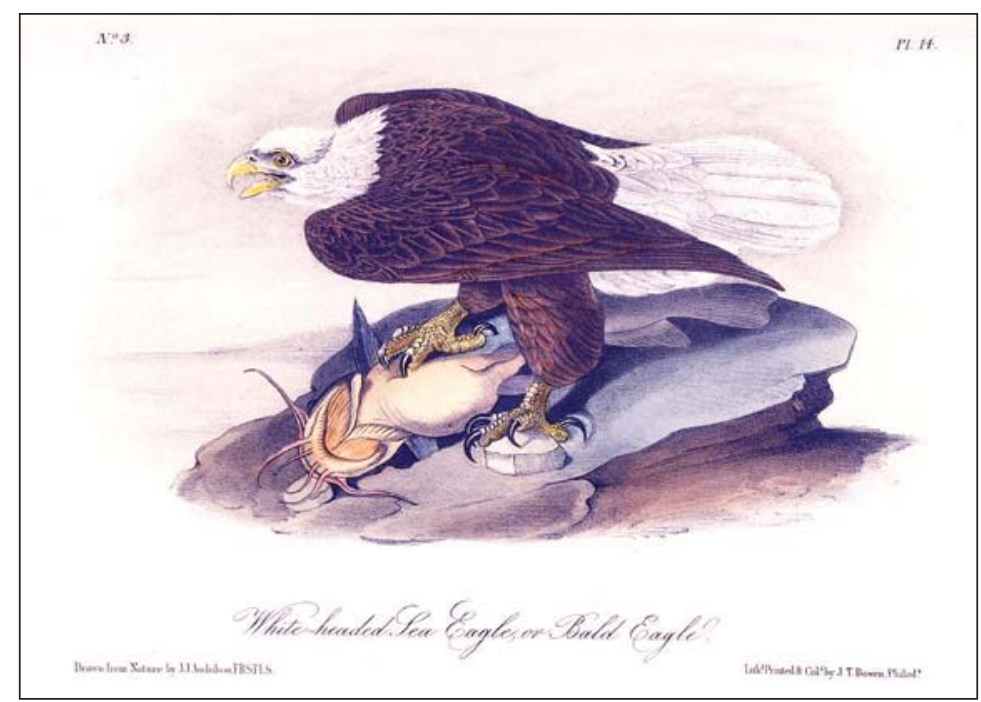

Figure 1. Painting of a bald eagle. Plate 14 in Vol. I, The Birds of America from Drawings made in the United States and their Territories by John James Audubon. V. G. Audubon, New York, 1856. Image provided courtesy of Bob D. Skiles.

Feature 23, a small pit northwest of Feature 18 (Figure 2) in a ca. $16^{\text {th }}$ century Zone H structure zone in the platform mound at the Hatchel site (41BW3) (Perttula 2014), contains the buried remains of an adult male bald eagle (Haliaeetus leucocephalus) (TARL n.d.289, 361-362), a unique discovery on an East Texas Caddo site. These remains were identified by noted avifaunal expert Dr. Lyndon Hargrave in June 1974. The bald eagle remains lay folded at the bottom of the pit (Figure 3), ca. $33 \mathrm{~cm}$ below the surface of Zone H.

Bald eagle remains were found in two burials at the late $17^{\text {th }}$-early $18^{\text {th }}$ century Cedar Grove site (3LA97) on the Red River, including a mostly complete bald eagle in Burial 2 (Trubowitz 1984:Figure 10-2) and a humerus fragment in Burial 3 (Styles and Purdue 1984:218). Finally, Webb (1959:36) noted the "articulated skeleton of a large bird, hawk or eagle" on the House 3 floor in Bossier phase (ca. A.D. 1200-1500) contexts at the Belcher Mound site (16CD13). It has subsequently been identified as a golden eagle (Jeffrey S. Girard, December 2013 personal communication).

The rarity of bald eagle and golden eagle skeletal remains on Caddo sites, and their known occurrence only in burial feature contexts (in both mound and habitation sites), suggests that eagle remains do not represent subsistence refuse. Rather, these remains are very likely the product of the use of captured eagles as sacra in feasting and ritual or religious ceremonies by the Caddo religious and political elite (the Xinesi 


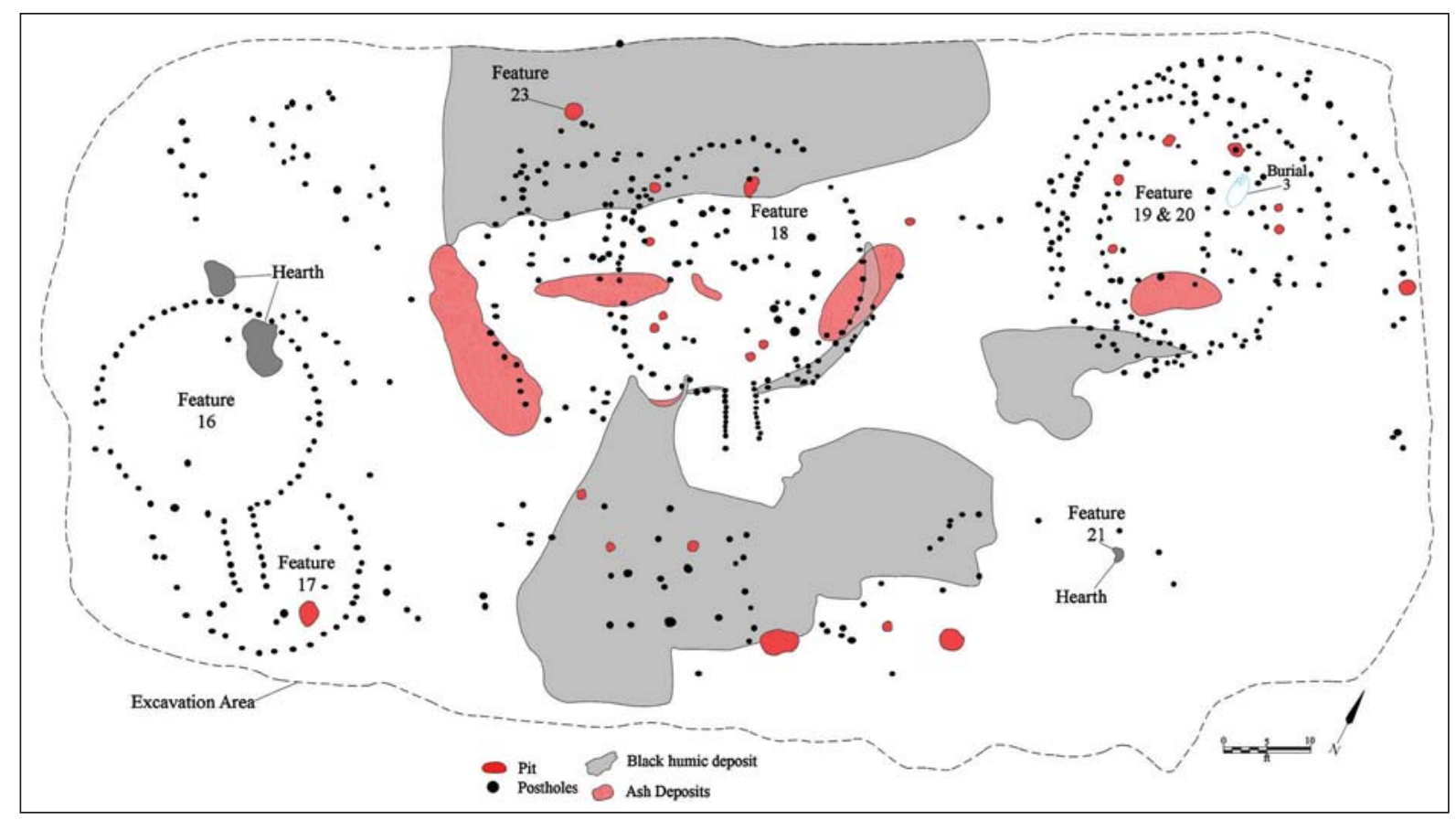

Figure 2. Structure zone $\mathrm{H}$ features, including Feature 23, in the platform mound at the Hatchel site. Figure prepared by Lance Trask.

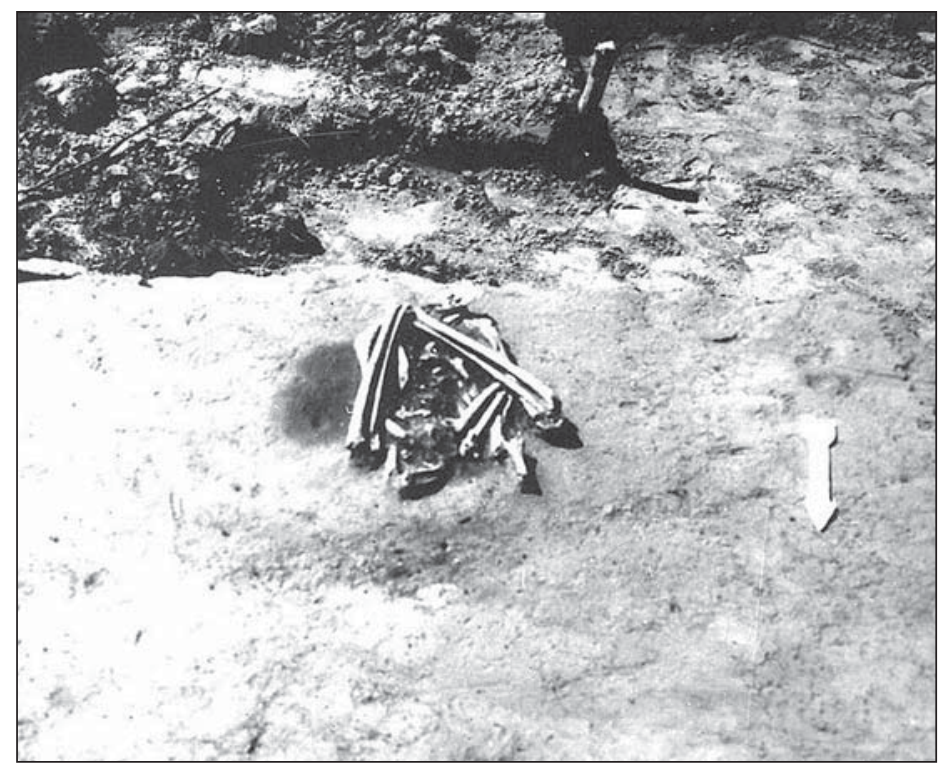

Figure 3. Bald eagle burial (Feature 23) in Structure Zone H at the Hatchel site. Image courtesy of the Texas Archeological Research Laboratory, The University of Texas at Austin. 
and $\mathrm{Caddi}$ ) that lived in different Red River communities. These majestic birds were fearsome hunters, with an awesome wing span, and were probably revered by Caddo peoples, but their use was likely reserved for the elite.

\section{REFERENCES CITED}

Perttula, T. K.

2014 Archaeological Studies of the Hatchel Site (41BW3) on the Red River in Bowie County, Texas. Special Publication No. 23. Friends of Northeast Texas Archaeology, Austin and Pittsburg.

Styles, B. W. and J. R. Purdue

1984 Faunal Exploitation at the Cedar Grove Site. In Cedar Grove: An Interdisciplinary Investigation of a Late Caddo Farmstead in the Red River Valley, edited by N. L. Trubowitz, pp. 211-226. Research Series No. 23. Arkansas Archeological Survey, Fayetteville.

Texas Archeological Research Laboratory, The University of Texas at Austin (TARL)

n.d. Field Notes, Site ET-30, A. J. Hatchel Place, 11 Miles Northwest of Texarkana, Bowie County, Texas, Excavated from November 1, 1938, to August 25, 1939. Binders No. 2-4. Notes on file at the Texas Archeological Research Laboratory, The University of Texas at Austin.

Trubowitz, N. L. (editor)

1984 Cedar Grove: An Interdisciplinary Investigation of a Late Caddo Farmstead in the Red River Valley. Research Series No. 23. Arkansas Archeological Survey, Fayetteville.

Webb, C. H.

1959 The Belcher Mound: A Stratified Caddoan Site in Caddo Parish, Louisiana. Memoirs No. 16. Society for American Archaeology, Salt Lake City. 